\title{
The Effect of Trustworthiness, Attractiveness, Expertise, and Popularity of Celebrity Endorsement
}

\author{
Yolanda Mayang Sari*, Rina Suthia Hayu, Muhartini Salim \\ Departement of Management, Faculty of Economic and Business, University of \\ Bengkulu, Bengkulu, Indonesia \\ *yolandamayangsari7@gmail.com
}

\begin{abstract}
This study aims to determine the impact of trust, attractiveness, expertise, and popularity (Suhay Salim) celebrity endorsement on the purchasing decisions of Korean skincare brand "Some By Mi" in Indonesia. The research method used in this research is quantitative research. Data was collected through an online questionnaire. This study involved 250 respondents who had bought and tried several skincare products "Some By Mi". Purposive sampling is used as a sampling strategy in this study, which uses a non-probability sampling methodology. Data collected from online questionnaires were analyzed using Multiple Linear Regression using SPSS 21.0 for Windows. The findings reveal that the trustworthiness, attractiveness, expertise, and popularity of celebrity endorsement Suhay Salim significantly and positively influence the public purchasing decision of Korean skincare brand "Some By Mi" partially.
\end{abstract}

Keywords: Attractiveness, Popularity, Purchase Decision, Trustworthiness

\section{INTRODUCTION}

The competition that is getting tougher in the adult business creates all kinds of opportunities. Various forms of competition that occur in the world's business that occur in everyday life, such as promotions carried out to advertise products in various electronic media, print media, and online media which have recently developed very rapidly. One of the communication strategies commonly used by companies to encourage and instill the positive impact of a product or service in the minds of customers is to ask for support from celebrities (Erdogan, 2010). Celebrity endorsement is one of the strategies commonly used today to help support various types of products, services, and brands. (Wei \& Wu, 2013) found that online celebrity endorsements intend to buy more than online customer reviews provided by someone. Celebrity endorsements use celebrities who enjoy public recognition and use that recognition on behalf of consumer goods by displaying them in advertisements (Chung \& Cho, 2017). Undoubtedly, a supporting celebrity cannot enhance a company's communication, position, and represent its brand. This is because the support from supporting celebrities can generate public awareness and public interest in an effective and efficient manner. The celebrity endorser chosen by the company is usually considered as someone who has an amazing way of life or extraordinary craftsmanship, is good looking, is well known and much liked (Malik \& Qureshi, 2016).

In recent years, the country's beauty industry has begun to be invaded by products such as skincare and cosmetics originating from South Korea. This happens because of the influence of K-Pop culture which has 
recently been increasingly in demand by Indonesians. The trend for facial skincare as clear as glass or glass skin has begun to mushroom in Indonesia recently. Today, Indonesian women have begun to realize that maintaining beauty, both physical and nonphysical, is important because appearance is a long-term asset and can increase one's selfconfidence. Skincare is a series of skincare products that can help maintain cleanliness and care for skin health if used regularly properly. According to a survey conducted by the ZAP Beauty Index 2018, where the survey results show that the definition of beauty according to Indonesian women is having clean, bright, and glowing skin. Based on research conducted by the Zap Beauty Index, almost all Indonesian women $(36 \%)$ use skincare at the age of 19-23 years. ZAP Beauty Index is an annual research publication issued by ZAP based on a survey of thousands of women who are consumers of the Indonesian beauty industry.

According to statistical data for 2019, the number of internet users in Indonesia reaches 197.2 million. A celebrity usually gives a review of the products they endorse on their social media accounts. Suhay Salim is one of the celebrities who often provide reviews about skincare through his YouTube and Instagram accounts. Suhay Salim is a well-known endorsement celebrity in Indonesia with 1.45 million subscribers on YouTube and 648 thousand followers on Instagram. One of the skincare that is often reviewed by Suhay Salim is skincare under the brand "Some By Mi".

"Some By Mi" is a South Korean skincare brand whose formula is famous for using natural ingredients and has a fairly affordable price. Through the review provided by Suhay Salim, it is easier for consumers to find references in choosing the right skincare before deciding to buy a facial skincare product. Purchasing decisions are a process in purchasing that is in the form of a real, whether consumers actually buy a product or not (Swastha \& Handoko, 2008). According to (Setiadi, 2003) consumer purchasing decisions are an integration process that integrates information to assess and select one of two or more alternative actions. This integration produces a choice, which is presented cognitively as a desire to behave. It begins with the stage of paying attention to a product or service and if it leaves an impression, the consumer will step into the stage of interest to find out the advantages of a product and if the intensity of the attraction is strong, it will continue to the desired stage because it is in accordance with their needs. If the desire and interest are so strong, then consumers will make a decision to buy (action to buy) the goods or services offered. Factors that influence purchasing decisions according to (Hanaysha, 2018) are price, human resources, product quality, and communication. In terms of price, when buying a product, consumers want an affordable price with good product quality. According to a Euromonitor International report titled The Future of Skincare, Indonesia is expected to become the world's largest skincare market, with strong demand in product purchase rates. The high level of skincare consumption in Indonesia makes skincare products have a great opportunity to be sold in the market. The skincare market accounted for $33 \%$ of the entire beauty market revenue in 2019 . Purchases of skincare made by consumers in Indonesia are usually through online shopping because the products are difficult to obtain offline or do not have the time to buy them directly. This study is a modification of the previous research by combining several variables in the previous study and making it one unit to be examined. The trustworthiness, attractiveness, and expertise characteristics were taken from research done by (Lombo \& Tielung, 2014) on Adidas product purchasing decisions. While the Popularity variable's supporting components were adapted from research conducted by (Gupta et al., 2017). This study aims to identify the dimensions of trustworthiness, attractiveness, expertise, and additional dimensions of popularity from celebrity endorser Suhay Salim regarding 
skincare products with the brand "Some By Mi", as has been done in previous studies in influencing purchasing decisions for "Some By Mi" skincare products in Indonesia, based on the above description.

\section{Purchase Decision}

The ultimate purchase behavior of consumers, both individuals, and families, who buy products and services for personal use is referred to as purchasing decision behavior (Kotler \& Amstrong, 2014). Consumer decision-making is a process in which persons make transactions in all aspects of their lives by interacting between emotional attitudes, cognitive attitudes, behavioral attitudes, and environmental conditions (Peter \& Olson, 2013). Cognitive attitudes represent comprehension attitudes, emotional attitudes reflect belief attitudes, and behavioral attitudes reflect actual action attitudes. When purchasing a product or service, purchase selections are made between two or more possibilities (Schiffman \& Kanuk, 2007).

According to Kotler \& Keller (2016), there are seven roles that people play in purchasing decisions, namely: initiator, users, influencer, decider, approvers, buyers, and gatekeepers. The purchase decision process goes through several stages carried out by consumers. These stages will produce a decision to purchase or not to buy and after buying the consumer will be satisfied or not. If satisfied, consumers will make repeat purchases or if not satisfied, consumers will switch to similar goods or services. According to Kotler \& Armstrong (2006) customers often go through five stages: problem identification, information gathering, alternative assessment, buying decisions, and post-buy behavior. Factors that influence purchasing decisions according to Kotler \& Armstrong (2006) are cultural influences, societal issues, personal factors, and psychological aspects are all important considerations. Indicators of purchasing decisions according to Kotler \& Armstrong (2006) are product diversity, brand quality, ease of getting a product, price of a product, need for a product.

\section{Trustworthiness}

The recipient's perception of the possibility that a supporter communicates the claim he believes to be the truest is referred to as trustworthiness, which refers to the sources' honesty, sincerity, and honesty, or in other words, the recipient's perception of the possibility that a supporter communicates the claim he believes to be the truest (Munnukka et al., 2016). In this case, trustworthiness is the level of trust conveyed by the communicator to his audience (Amos et al., 2008). It also means consumer trust in sources to provide information objectively and honestly (Ohanian, 1990). Consumers' trustworthiness may be defined as honesty, integrity, and celebrity trust in the context of celebrity endorsement. This can lead to trust and acceptance of the celebrity endorser and the inherent message the celebrity conveys to consumers. So that in the long run, it can help influence beliefs, attitudes, opinions, and buying behavior (Ohanian, 1990). The term "trust" encompasses a wide range of source credibility where it is believed that the level of acceptance of a message depends on the level of credibility an endorser has. Studies show that when communicators are considered highly trustworthy, opinionated messages are more effective than nonopinion messages in producing attitude change (Ohanian, 1990).

Trustworthiness is an endorser considered as a person who can be relied on or trusted. This is related to the honesty, trustworthiness, integrity of an endorser. In recommending a product, the trustworthiness of an endorser greatly affects consumers (Hovland et al., 1953). Trustworthiness refers to the extent to which endorsers are seen as honest, trustworthy, and sincere. Endorsers can be trusted in communicating a product, endorsers can make consumers believe in the products delivered. In this case, consumers do not have to know the endorser, however, consumers can assess the appropriateness of the endorser in 
advertising or providing a review of a product. Trust refers to the amount of trust and level of acceptance shown by the audience towards the communicator (Lord \& Putrevu, 2009).

\section{Attractiveness}

Shimp

(2007) explains that attractiveness refers to the attractiveness contained in an endorser which can attract the attention of consumers to be seen. When consumers find something that they are attractive and like in an endorser, persuasion will work through identification. This means that consumers will adopt the attitude or preference of the endorser when they find something attractive that they like. Celebrities who have physical attractiveness show a positive impact on the products they advertise, and this will certainly lead to a person's purchasing decision for the advertised product.

Till \& Busler (2000) defines celebrity attractiveness in various aspects. This includes not only physical or facial beauty but other manifestations of beauty such as sportsmanship, charm, elegance, and intelligence. According to Gupta et al. (2017) physical, attractiveness is an informational requirement that involves a subtle, pervasive, and absolute effect. Physical attractiveness refers to a person's first impression of others about physical characteristics, such as height and physical beauty, elegance, attitude, and ethics (Lord \& Putrevu, 2009). Increasing the trustworthiness aspect of an endorser is the most effective way to increase the level of consumer confidence in a product (Huang et al., 2014). The potential appeal of an endorser is the ability to transmit meaning successfully when contrasted to less attractive sources, such that celebrity attractiveness positively influences brand image.

Attractiveness is something that can increase the interest and attention of most people. This is not only limited to body shape, but includes all the physical attributes of the endorser, such as facial features, hair color, and physical appearance. In addition, the personality of an endorser, the things he likes, and the things he has in common with consumers, and the lifestyle that consumers feel will also influence the interpretation of attractiveness.

\section{Expertise}

The degree to which communicators are regarded as a source of valid claims is defined as expertise (Spry et al., 2011). They are usually supported by professional knowledge and skills so that their claims about the product become a factor that can increase persuasion to consumers. Some researchers believe that skilled endorsers will have more potential than those with only physical attractiveness (Silvera \& Austad, 2004). Expertise refers to the information, experience, and abilities that endorsers possess (Chung \& Cho, 2017). An expert endorser generates a higher interest for the target audience to buy a product (Ohanian, 1990). Spry et al. (2011) said that an endorser's knowledge is connected to the veracity of claims about a product, which is a significant component in improving the persuasive ability of the given advertising. More specifically, the expertise of an endorser is proportional to the correctness of the information conveyed about the product and thus is able to form a more positive brand attitude (Magnini et al., 2010).

People's views of an endorser's knowledge, experience, or abilities determine their competence. The perception of this knowledge, experience, or skills influences the way the audience will judge the quality of the product offered by an endorser (Magnini et al., 2010). If a celebrity who promotes a product has extensive knowledge and expertise, he or she will eventually have distinct talents to pursue since they have strong convictions (Jamil \& Hassan, 2014). When a celebrity has an understanding of the things they are advertising, this is referred to as knowledge. Meanwhile, experience is when a celebrity has experience in conveying information related to a product it supports or has 
experience in the advertised field (beauty influencer). Endorser competence is comparable to source qualification in that it directly impacts the level of trust in persuading consumers to buy sponsored items (Wang \& Scheinbaum, 2018).

\section{Popularity}

Large fan bases, a track record of successful performance, celebrity likes, an uncontroversial celebrity image, and whether the celebrity is a role model for others all contribute to the popularity of celebrity endorsements (Gupta et al., 2017). An endorser is described as someone with enough personality to be noticed by the audience. In general, the endorser chosen is someone who is well known and has wide influence among the community, so that public attention can be diverted to the advertised brand. How much popularity, also known as visibility, does a celebrity endorser have? When combined with fame, it can be useful if the purpose of communication is to increase brand awareness (Ahmed et al., 2014).

The theoretical foundation gained from the examined literature and comprehension of the ideas thus far has helped to the formulation of the following hypotheses:

$\mathrm{H}_{1}$ :Trustworthiness celebrity endorsers significantly affects toward purchase decision.

$\mathrm{H}_{2}$ :Attractiveness celebrity endorsers significantly affects toward purchase decision.

$\mathrm{H}_{3}$ :Expertise celebrity endorsers signifycantly affects toward purchase decision.

$\mathrm{H}_{4}$ :Popularity celebrity endorsers signifycantly affects toward purchase decision.

\section{METHODS}

The unit of analysis in this research is individuals who buy and use Korean Skincare "Some By Mi" products in Indonesia. This research collects data from respondents in Indonesia using a crosssectional technique. The data was collected through purposive sampling during 19-29 March 2021 using an independent questionnaire. The questionnaire was created in Google Forms and disseminated online using the Instagram, WhatsApp, Line, Twitter, Facebook, and Telegram apps. Screening is done to verify that all responders are from Indonesia and use and purchase "Some By Mi" Korean Skincare goods. The questionnaire consists of three main parts, namely the characteristics of the respondents (Table 1), the measurement of the independent and dependent variables.

Table 1. Respondent Characteristics

\begin{tabular}{|c|c|c|}
\hline \multicolumn{2}{|c|}{ Respondents Characteristics } & Percentage \\
\hline \multirow[t]{2}{*}{ Gender } & Men & 12.6 \\
\hline & Women & 87.4 \\
\hline \multirow[t]{3}{*}{ Age } & $16-25$ years & 91.6 \\
\hline & 26-35 years & 4.4 \\
\hline & $36-45$ years & 4 \\
\hline \multirow[t]{5}{*}{ Residence } & Sumatera & 31.2 \\
\hline & Java & 65.1 \\
\hline & Kalimantan & 1.6 \\
\hline & Sulawesi & 1.3 \\
\hline & Bali & 0.8 \\
\hline \multirow[t]{6}{*}{ Job } & PNS/TNI/ POLRI & 7.2 \\
\hline & Private employees & 3.2 \\
\hline & BUMN employees & 0.8 \\
\hline & Housewife & 3.2 \\
\hline & Student / Student & 82.8 \\
\hline & Etc & 2.8 \\
\hline \multirow[t]{5}{*}{ Last Education } & Senior High School & 71.2 \\
\hline & D3 & 7.2 \\
\hline & Bachelor & 18.4 \\
\hline & Master & 2.4 \\
\hline & Doctor & 0.8 \\
\hline \multirow{7}{*}{$\begin{array}{l}\text { Earn Per } \\
\text { Month }\end{array}$} & Rp1.000.000- & \\
\hline & Rp5.000.000 & 79.6 \\
\hline & Rp5.000.000 - & \\
\hline & Rp10.000.000 & 17.6 \\
\hline & Rp10.000.000 - & \\
\hline & Rp15.000.000 & 2.4 \\
\hline & $>\mathrm{Rp} 15.000 .000$ & - \\
\hline
\end{tabular}

All measurements are based on the subjective assessment of respondents using a five-point Likert scale ( $1=$ strongly disagree to $5=$ strongly agree). A total of 24 measurement items were adapted from existing measures in the literature to ensure content validity (Table 2). Predetermined criteria are used to determine the quantity of samples Hair et al., (2010) it specifies that the number of respondents gathered must be 
at least 5 times the number of indicators used in the research and no more than 10 times the number of indicators used in the study. Then the number of samples is 240 respondents. This study gathered 250 respondents in order to overcome the questionnaire that was incompletely filled out by the respondent or the questionnaire was regarded as a failure. The data was then examined using multiple linear analysis methods with the SPSS 21.0 for Windows software.

\section{RESULTS AND DISCUSSION}

Individuals who buy and utilize Korean Skincare "Some By Mi" goods were polled for 250 surveys, which were then analyzed using SPSS 21.0 for Windows using multiple linear regression analysis techniques. Women dominated this study's respondents $(87.4 \%)$, with the age group 1625 years $(91.6 \%)$, working as students (82.8\%), living in Java (65.1\%), having a senior high school $(71.2 \%)$, and earning Rp. $1,000,000$ - Rp. 5,000,000 per month $(79.6 \%)$. Can be seen in Table 1 .

The validity test is used to ensure that a study measuring equipment is capable of producing results that are appropriate for its intended usage. The validity test is a test conducted to find out how well a research statement item can be used to measure research variables (Sekaran \& Bougie, 2013). The questionnaire used in this study has never been used before, therefore it is necessary to test its validity. The validity coefficient known as the corrected item or total correlation or the correction item correlation coefficient was used to empirically assess the question items ( $\mathrm{r}$ value). Each question item is said to be valid and acceptable if $r$ value $>r$ table (with $n-2$, $\alpha=0.05$ ) and vice versa if $r$ value $<r$ table then each item of the instrument is declared invalid (Ghozali, 2013). To measure the error, it can be seen that the items owned by $r$ table 0.266 or greater. So if the item score correlation is less than 0.266 then the instrument item is declared invalid (Santoso, 2005). Based on Table 2, the results of the validity test on the purchase decision, trustworthiness, attractiveness, expertise, and popularity celebrity endorsement variables indicate that the data item statement on these variables is valid.

Table 2. SPSS Result Of Validity And Realibilty Measures

\begin{tabular}{|c|c|c|c|c|c|}
\hline Variable & & Measurement Item & Validity & $\begin{array}{l}\text { Reali } \\
\text { bility }\end{array}$ & $\begin{array}{l}\text { Source } \\
\text { (Adapted } \\
\text { from) }\end{array}$ \\
\hline \multirow[t]{4}{*}{$\begin{array}{l}\text { Trustworth } \\
\text { iness }\end{array}$} & TW1 & $\begin{array}{l}\text { I feel Suhay Salim is } \\
\text { honest in giving } \\
\text { "Some By Mi" } \\
\text { skincare product } \\
\text { reviews }\end{array}$ & $0.784^{* * *}$ & \multirow[t]{4}{*}{0,780} & \multirow[t]{4}{*}{$\begin{array}{l}\text { Munnukk } \\
\text { a et al., } \\
\text { (2016) }\end{array}$} \\
\hline & TW2 & $\begin{array}{l}\text { I feel Suhay Salim is } \\
\text { telling the truth in } \\
\text { giving "Some By } \\
\text { Mi" skincare product } \\
\text { reviews }\end{array}$ & $0.755^{* *}$ & & \\
\hline & TW 3 & $\begin{array}{l}\text { I feel Suhay Salim is } \\
\text { serious about giving } \\
\text { "Some By Mi" } \\
\text { skincare product } \\
\text { reviews }\end{array}$ & $0.751 * *$ & & \\
\hline & TW4 & $\begin{array}{l}\text { I feel Suhay Salim } \\
\text { can be trusted in } \\
\text { providing "Some By } \\
\text { Mi" skincare product } \\
\text { reviews }\end{array}$ & $0.812 * *$ & & \\
\hline \multirow[t]{6}{*}{$\begin{array}{l}\text { Attractive } \\
\text { ness }\end{array}$} & ATT1 & $\begin{array}{l}\text { I think Suhay Salim } \\
\text { is stylish }\end{array}$ & $0.709^{* * *}$ & \multirow[t]{6}{*}{0,852} & \multirow[t]{6}{*}{$\begin{array}{l}\text { Gupta et } \\
\text { al. (2017) }\end{array}$} \\
\hline & ATT2 & $\begin{array}{l}\text { I find Suhay Salim } \\
\text { attractive }\end{array}$ & $0.750 * *$ & & \\
\hline & ATT3 & $\begin{array}{l}\text { I think Suhay Salim } \\
\text { is sexy }\end{array}$ & $0.792 * *$ & & \\
\hline & ATT4 & $\begin{array}{l}\text { I think Suhay Salim } \\
\text { is elegant }\end{array}$ & $0.762 * *$ & & \\
\hline & ATT5 & $\begin{array}{l}\text { I think Suhay Salim } \\
\text { is beautiful }\end{array}$ & $0.759 * *$ & & \\
\hline & ATT6 & $\begin{array}{l}\text { I feel that Suhay } \\
\text { Salim is classy }\end{array}$ & $0.766^{* * *}$ & & \\
\hline \multirow[t]{5}{*}{ Expertise } & EXP1 & $\begin{array}{l}\text { I feel Suhay Salim } \\
\text { has the knowledge in } \\
\text { providing "Some By } \\
\text { Mi" skincare product } \\
\text { reviews }\end{array}$ & $0.696^{* * *}$ & \multirow[t]{5}{*}{0,802} & \multirow[t]{5}{*}{$\begin{array}{l}\text { Malik \& } \\
\text { Sudhakar } \\
\text { (2014) }\end{array}$} \\
\hline & EXP2 & $\begin{array}{l}\text { I feel Suhay Salim } \\
\text { has experience in } \\
\text { providing "Some By } \\
\text { Mi" skincare product } \\
\text { reviews. }\end{array}$ & $0.751 * *$ & & \\
\hline & EXP3 & $\begin{array}{l}\text { I feel Suhay Salim } \\
\text { has the skills to } \\
\text { provide "Some By } \\
\text { Mi" skincare product } \\
\text { reviews }\end{array}$ & $0.792 * *$ & & \\
\hline & EXP4 & $\begin{array}{l}\text { I feel Suhay Salim } \\
\text { has the quality in } \\
\text { providing "Some By }\end{array}$ & $0.741 * *$ & & \\
\hline & EXP5 & $\begin{array}{l}\text { Mi" skincare product } \\
\text { reviews } \\
\text { I feel Suhay Salim is } \\
\text { an expert in } \\
\text { providing "Some By } \\
\text { Mi" skincare product } \\
\text { reviews }\end{array}$ & $0.760 * *$ & & \\
\hline \multirow[t]{4}{*}{ Popularity } & POP1 & $\begin{array}{l}\text { I feel Suhay Salim } \\
\text { has a lot of followers } \\
\text { and subscribers on } \\
\text { social media }\end{array}$ & $0.713^{* * *}$ & \multirow[t]{4}{*}{0,768} & \multirow[t]{4}{*}{$\begin{array}{l}\text { Gupta et } \\
\text { al. (2017) }\end{array}$} \\
\hline & POP2 & $\begin{array}{l}\text { I find Suhay Salim } \\
\text { pleasant in giving a } \\
\text { review of "Some By } \\
\text { Mi" skincare } \\
\text { products }\end{array}$ & $0.808 * *$ & & \\
\hline & POP3 & $\begin{array}{l}\text { I feel Suhay Salim } \\
\text { has a good track }\end{array}$ & $0.765 * *$ & & \\
\hline & POP4 & $\begin{array}{l}\text { record of } \\
\text { performance } \\
\text { I consider Suhay } \\
\text { Salim a role model in } \\
\text { providing "Some By } \\
\text { Mi" skincare product } \\
\text { reviews }\end{array}$ & $0.786 * *$ & & \\
\hline $\begin{array}{l}\text { Purchase } \\
\text { Decision }\end{array}$ & PD1 & $\begin{array}{l}\text { I decided to buy } \\
\text { "Some By Mi" } \\
\text { skincare products } \\
\text { because "Some By } \\
\text { Mi" skincare } \\
\text { products have a wide } \\
\text { variety of product } \\
\text { variants to choose }\end{array}$ & $0.748^{*}$ & 0,840 & $\begin{array}{l}\text { Gupta et } \\
\text { al. (2017) } \\
\text { Kotler \& } \\
\text { Amstrong } \\
(2016) \\
(2006)\end{array}$ \\
\hline
\end{tabular}




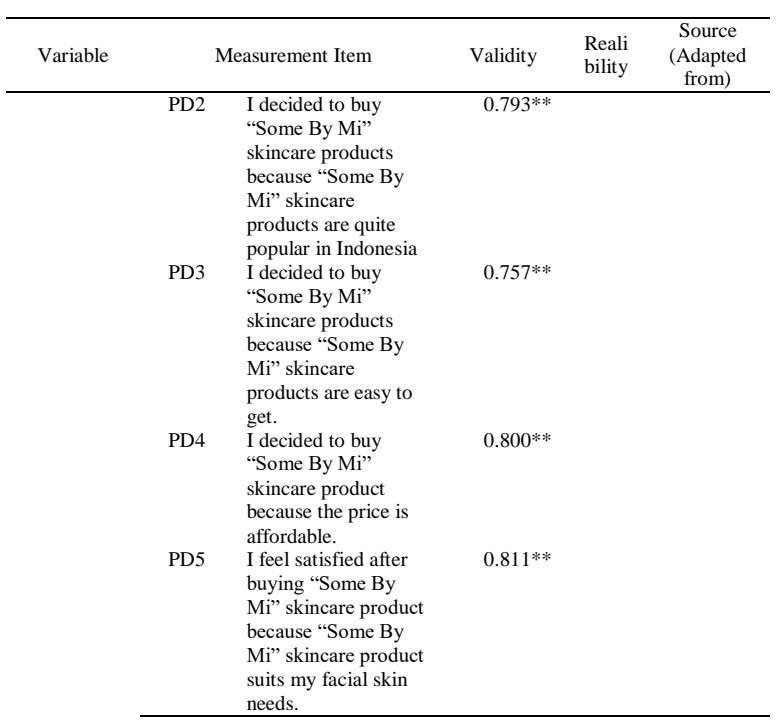

The reliability test is a questionnaire testing instrument that serves as a variable indicator. If a person's response to a statement is constant or stable throughout time, the questionnaire is considered to be dependable (Ghozali, 2006). Reliability testing in this study used an analytical technique developed by Cronbach's Alpha. In this reliability test, it is declared reliable if Cronbach's Alpha is greater than constant $>0.6$ (Ghozali, 2013). The assessment of dependability may be done in a single brief/single measurement, then the findings can be compared to other questions or the correlation between the responses to the questions can be measured. Reliability test was carried out with the help of SPPS 21.0 for window with Cronbach's alpha statistical test. Because this research instrument is in the form of a questionnaire and a multidimensional scale, the alpha score is calculated. Table 3 shows that the variable trustworthiness, attractiveness, expertise, and popularity celebrity endorsement towards purchase decision has a high reliability value, which is greater than 0.60 , implying that the variables trustworthiness, attractiveness, expertise, and popularity celebrity endorsement towards purchase decision are high and can be used.

The SPSS 21.0 software for Windows was used to examine the connection between the independent factors and the dependent variable in this study. Multiple linear analysis refers to the connection between a variable and more than one independent variable. A popular statistical approach for examining the connection between a dependent variable and an independent variable is multiple linear analysis. Multiple regression analysis is used to determine the strength of a connection between two or more variables. Multiple linear regression analysis is used to assess the strength of the link between the factors of trust, attractiveness, competence, and popularity and the choice to purchase "Some By Mi" skin care products. The results of data processing in brief can be seen in Table 3.

Table 3. SPSS Result of Multiple Regression Analysis

\begin{tabular}{cccccc}
\hline Hyphothesis & Relationship & $\beta$ & $\begin{array}{c}\mathrm{t} \\
\text { value }\end{array}$ & Sig & R2 \\
\hline $\mathrm{H}_{1}$ & TW => PD & 0.207 & 2.049 & 0.042 & 0.671 \\
$\mathrm{H}_{2}$ & ATT => PD & 0.237 & 3.742 & 0.000 & \\
$\mathrm{H}_{3}$ & EXP => PD & 0.209 & 2.636 & 0.009 & \\
$\mathrm{H}_{4}$ & POP => PD & 0.264 & 2.639 & 0.009 & \\
\hline
\end{tabular}

According to the findings of this study, the influence of celebrity endorser trustworthiness Suhay Salim on purchase decisions is positive and significant, with the trustworthiness regression coefficient value of 0.207 and a significance value of 0.042 alpha 0.05 with $t$ value $>\mathrm{t}$ table $(2.049)>$ (0.266). This shows that the increasing the trustworthiness of a celebrity endorser Suhay Salim, the more the decision to buy Korean skincare products "Some By Mi" will increase.

This study obtained the same findings as research by (Guesh, 2019) trustworthiness influences customer purchase decisions for fast moving consumer goods products. This study's findings are also consistent with earlier studies (Park \& Lin, 2020) that trustworthiness can influence purchasing decisions.

According to the findings of a study on the influence of celebrity endorser Suhay Salim's attractiveness on purchasing decisions, It is stated in this study that attractiveness Where the attractiveness regression coefficient value is, there is a positive and significant influence on purchase decisions. 0.237 and a significance 
value of $0.000<$ alpha 0.05 with $\mathrm{t}$ value $\mathrm{t}>\mathrm{t}$ table $(3.742>0.266)$. This demonstrates the increasing attractiveness of a celebrity endorser Suhay Salim, the higher the level of purchasing decisions for Korean skincare products "Some By Mi". This study is consistent with prior studies (Mansour \& Diab, 2016) that celebrity endorsers' beauty has a favorable and significant impact on Sudanese customer purchasing attitudes and behavior.

According to the research results, the influence of celebrity endorser Suhay Salim's expertise on purchasing decisions According to this study, expertise has a positive and substantial influence on purchase decisions, with the expertise regression coefficient being 0.264 and the significance value is 0.009 < alpha 0.05 with $\mathrm{t}$ value > t table (2.636. > 0.266). This shows that the more expertise a celebrity endorser Suhay Salim has, the more the decision to buy Korean skincare products "Some By Mi" will increase. This study backs up earlier studies (Sheu, 2010) that the celebrity endorser expertise has a positive impact on customer purchase decisions for athletic footwear.

The influence of popularity of celebrity endorser Suhay Salim on purchasing decisions in this study, states that popularity has a positive and significant effect on purchasing decisions, where the regression coefficient of awareness is 0.425 and a significance value of $0.009<$ alpha 0.05 with a value of $t$-value> t-table $(2.639>0.266)$. This shows that the increasing popularity of a celebrity endorser Suhay Salim, the higher the level of purchasing decisions for Korean skincare products "Some By Mi". This study obtained the same findings as previous research by (Jin \& Ryu, 2020) that the popularity of a celebrity can influence consumers to buy a product. The research findings show that consumers will be more likely to buy the product if the product is endorsed by a well-known celebrity. In addition, the results of this study are also in line with previous research conducted by (Zipporah \& Mberia, 2014) that the level of popularity of a celebrity can have a significant effect on consumer purchasing decisions in the products it advertises.

Marketers of Korean skincare products "Some By Mi" in Indonesia must consider the importance of trustworthiness, physical attractiveness, expertise, and popularity of celebrity endorser Suhay Salim, and how to apply it effectively in advertising and promotion systems if they are to seize the youth market. Because according to the research results, these factors have a positive and significant impact on consumer purchasing decisions for Korean Skin Care products in the "Some By Mi" category.

\section{Conclusion}

The variable trustworthiness celebrity endorser Suhay Salim partially has a positive and significant effect on purchasing decisions for Korean skincare products "Some By Mi", which means that the higher the level of trustworthiness, the higher the decision to purchase Korean skincare products "Some By Mi". The attractiveness variable celebrity endorser Suhay Salim partially has a positive and significant effect on purchasing decisions for Korean skincare products "Some By Mi", which means that the higher the level of attractiveness, the higher the decision to buy Korean skincare products "Some By Mi". The variable (expertise) celebrity endorser Suhay Salim partially has a positive and significant effect on the decision to purchase Korean skincare products "Some By Mi", which means that the higher the level of expertise, the higher the decision to buy Korean skincare products "Some By Mi". The variable popularity of celebrity endorser Suhay Salim partially has a positive and significant effect on the decision to buy Korean skincare products "Some By Mi", which means that the higher the level of popularity, the higher the decision to buy some Korean skincare products by mi.

\section{REFERENCES}

Ahmed, N., Farooq, O., \& Iqbal, J. (2014). Credibility of celebrity endorsement and buying intentions an evidence from 
students of Islamabad, Pakistan. International Letters of Social and Humanistic Sciences, 20(January), 113.

Amos, C., Holmes, G., \& Strutton, D. (2008). Exploring the relationship between celebrity endorser effects and advertising effectiveness: A quantitative synthesis of effect size. International Journal of Advertising, 27(2), 209-234.

Swastha, B., \& Handoko, T. H. (2008) Manajemen Pemasaran, Analisa. Perilaku Konsumen. Edisi Pertama. Cetakan Keempat. Jakarta: Penerbit BPFE.

Chung, S., \& Cho, H. (2017). Fostering parasocial relationships with celebrities on social media: Implications for celebrity endorsement. Psychology and Marketing, 34(4), 481-495.

Guesh, E. (2019). The effect of celebrity endorsement on consumer buying behavior: the case of fast moving consumer goods (FMCGS) in Addis Ababa. Doctoral dissertation. St. Mary's University.

Erdogan, B. (2010). Celebrity endorsement : A literature review celebrity endorsement: A literature review. Journal of Marketing Management, 772858957, 37-41.

Ghozali, I. (2006). Aplikasi analisis multivariat dengan Program IBM SPSS. Edisi 4. Semarang: Badan Penerbit Universitas Diponegoro

Ghozali, I. (2013). Aplikasi analisis multivariat dengan Program IBM SPSS. Edisi 7. Semarang: Badan Penerbit Universitas Diponegoro.

Gupta, R., Kishor, N., \& Verma, D. P. S. (2017). Construction and validation of a five-dimensional celebrity endorsement scale: introducing the pater model. British Journal of Marketing Studies, 5(4), 15-35.

Hair, J. F., Anderson, R. E., Tatham, R. L., \& Black, W. C. (2010). Multivariate Data Analysis. $7^{\text {th }}$ Edition. New York:Prentice Hall International, Inc.

Hanaysha, J. R. (2018). An examination of the factors affecting consumer's purchase decision in the Malaysian retail market. PSU Research Review, 2(1), 7-23.

Mansour, I. H. F., \& Diab, D. M. E. (2016). The relationship between celebrities' credibility and advertising effectiveness: The mediation role of religiosity. Journal of Islamic Marketing, 7(2), 148-166.

Huang, Y. C., Yang, M., \& Wang, Y. C. (2014). Effects of green brand on green purchase intention. Marketing Intelligence and Planning, 32(3), 250268.

Malik, H. M., \& Qureshi, M. M. (2016). The impact of celebrity endorsement on consumer buying behavior. Journal of Marketing and Consumer Research, 26, $1-121$.

Hovland, C. I., Janis, I. L., \& Kelley, H. H. (1953). Communication and Persuasion; Psychological Studies of Opinion Change. New Haven: Yale University Press.

Jamil, R. A., \& Hassan, S. R. ul. (2014). Influence of celebrity endorsement on consumer purchase intention for existing products: a comparative study. Journal of Management Info, 1(4), 1-8.

Jin, S. V., \& Ryu, E. (2020). “ I' 11 buy what she's \# wearing": The roles of envy toward and parasocial interaction with influencers in Instagram celebrity-based brand endorsement and social commerce. Journal of Retailing and Consumer Services, 55(November 2019), 102121.

Kotler, P., \& Armstrong, G. (2006). Prinsipprinsip Pemasaran. Edisi keduabelas. Jilid 1. Northwestern University

Kotler, P., \& Armstrong, G. (2014). Principle of Marketing. $15^{\text {th }}$ Edition. New Jersey: Pearson Prentice Hall.

Kotler, P., \& Keller, K. L. (2016), Marketing Management. $15^{\text {th }}$ Edition. Pearson Education Limited.

Lombo, V. E. P., \& Tielung, M. V. (2014). The impact of celebrity endorsement to youth consumer purchase decision on 
Adidas apparel product. Jurnal EMBA: Jurnal Riset Ekonomi, Manajemen, Bisnis dan Akuntansi, 2(3), 1246-1254.

Lord, K. R., \& Putrevu, S. (2009). Informational and transformational responses to celebrity endorsements. Journal of Current Issues and Research in Advertising, 31(1), 1-13.

Magnini, V. P., Garcia, C., \& Honeycutt, E. D. (2010). Identifying the attributes of an effective restaurant chain endorser. Cornell Hospitality Quarterly, 51(2), 238-250.

Malik, A., \& Sudhakar, B. D. (2014). Brand positioning through celebrity endorsement - a review contribution to brand literature. International Review of Management and Marketing, 4(4), 259275.

Munnukka, J., Uusitalo, O., \& Toivonen, H. (2016). Credibility of a peer endorser and advertising effectiveness. Journal of Consumer Marketing, 33(3), 182192.

Ohanian, R. (1990). Construction and validation of a scale to measure celebrity endorsers' perceived expertise, trustworthiness, and attractiveness. Journal of Advertising, 19(3), 39-52.

Park, H. J., \& Lin, L. M. (2020). The effects of match-ups on the consumer attitudes toward internet celebrities and their live streaming contents in the context of product endorsement. Journal of Retailing and Consumer Services, 52(May 2019), 101934.

Peter, J. P., \& Olson, J. C. (2013). Perilaku Konsumen dan Strategi Pemasaran. Jilid 1. Jakarta: Salemba Empat.

Santoso, G. (2005). Metodologi Penelitian Kualitatif dan Kuantitatif. Jakarta: Prestasi Pustaka.

Schiffman, L, \& Kanuk, L. L. (2007). Consumer Behaviour. $7^{\text {th }}$ Edition. Jakarta: PT. Indeks

Setiadi, N. J. (2003). Perilaku Konsumen: Konsep dan Implikasi untuk Strategi dan Penelitian Pemasaran. Jakarta: Kencana.

Sheu, J. (2010). A hybrid dynamic forecast model for analyzing celebrity endorsement effects on consumer attitudes. Mathematical and Computer Modelling, 52(9-10), 1554-1569.

Shimp, T. A. (2003). Periklanan promosi \& aspek tambahan komunikasi. Pemasaran. Terpadu, Jilid I (Edisi 5), Jakarta: Erlangga.

Silvera, D. H., \& Austad, B. (2004). Factors predicting the effectiveness of celebrity endorsement advertisements. European Journal of Marketing, 38(11/12), 15091526.

Spry, A., Pappu, R., \& Cornwell, T. B. (2011). Celebrity endorsement, brand credibility and brand equity. European Journal of Marketing, 45(6), 882-909.

Till, B. D., \& Busler, M. (2000). The matchup hypothesis: Physical attractiveness, expertise, and the role of fit on brand attitude, purchase intent and brand beliefs. Journal of Advertising, 29(3), $\mathrm{X}-13$.

Wang, S. W., \& Scheinbaum, A. C. (2018). Enhancing brand credibility via celebrity endorsement trustworthiness trumps attractiveness and expertise. Journal of Advertising Research, 58(1), 16-32.

Wei, K. K., \& Wu, Y. L. (2013). Measuring the impact of celebrity endorsement on consumer behavioural intentions: A study of Malaysian consumers.. International Journal of Sports Marketing and Sponsorship, 14(3), 222.

Zipporah, M. M., \& Mberia, H. K. (2014). The effects of celebrity endorsement in advertisements. International Journal of Academic Research in Economics and Management Sciences, 3(5), 178-188. 